\title{
Temporal and spatial infiltration characteristics of soil under acacia and pine plantations in the mountainous area of Van Don, Quang Ninh, Vietnam
}

\author{
Đặc điểm thấm nước theo không gian và thời gian của đất dưới rừng trồng thông và keo tại \\ vùng núi Vân Đồn, Quảng Ninh, Việt Nam
}

\author{
BUI, Xuan Dung1*; VU, Thi Hoai Thu¹; NGUYEN, Thi My Linh¹; GOMI, Takashi²
}

${ }^{1}$ Vietnam National University of Forestry, Faculty of Forest Resources and Environmental Management, Hanoi, Vietnam; ${ }^{2}$ Tokyo University of Agriculture and Technology, Department of International Environmental and Agricultural Science, 3-5-8 Saiwaicho, Fuchu, Tokyo $183-8509$ Japan

\begin{abstract}
To determine the soil infiltration characteristics of pine and acacia plantations, we used a double-ring infiltrometer in 15 different locations of up-hill, mid-hill and down-hill part in each kind of plantation from June to August, 2018. The spatial infiltration characteristics of the soil at three plots (with no tree, with acacia tree and with pine tree) was determined by dye tracer method. The factors having an impact to the infiltration process were also analyzed. The main findings include: (1) The soil infiltration rate under both pine and acacia plantation decreased over time and it was the highest in the bottom of the hill and the lowest in the middle of the hill. The infiltration rate and the total infiltrated water in one hour at the acacia plantation were higher than ones at the pine plantation. However, statistical significant difference was only found for stable infiltration rate between two plantations; (2) The area and the depth of infiltrated water were the highest at the plot without trees, smaller at the soil of acacia plot and smallest at the soil of pine plot. All spatial infiltration rates were within the findings of previous studies; (3) The result indicated that soil with high ground cover has high infiltration rate.
\end{abstract}

Để xác định đặc điểm thấm nước của đất dưới rừng trồng Thông và Keo, vòng đôi đo tốc độ thấm đã được sử dung để đo ở sườn trên, sườn giữa và sườn dưới (5 lần/ ví trí) cho mỗi loại hinh rừng từ tháng 6-8/2018. Trong khi, thuốc nhuộm được sử dụng để kiểm tra đặc điểm thấm nước của đất theo không gian trên 3 ô (ô không có cây, ô trồng Keo và ô trồng Thông). Các yếu tố ảnh hưởng đến đặc điểm thấm nước cũng được phân tích. Kết quả chính thu được: (1) Tốc độ thấm ở cả hai loại rừng giảm dần theo thời gian và cao nhất ở sườn dưới, nhỏ nhất ở sườn giữa. Cả tốc độ thấm và tổng lượng nước thấm trong một giờ của rừng keo đều cao hơn so với rừng Thông. Tuy nhiên, chi có tốc độ thấm ổn định là khác biệt có ý nghĩa thống kê; (2) Diện tích và độ sâu nước thấm xuống đất cao nhất ở ô không có cây, nhỏ hơn ở ô trồng Keo và nhỏ nhất ở ô trồng Thông; (3) Độ che phủ thực vật càng cao thi lượng nước thấm càng lớn.

Keywords: acacia plantation, dye tracer, infiltration rate, pine plantation, spatial infiltration

\section{Introduction}

Soil infiltration is the process in which water entries downward into the immediate surface of soil or other materials (Horton, 1933). In both arid and semi-arid areas, soil infiltration is recognized as a fundamental ecological process that affects the water budget of vegetation, runoff, and the related risk of soil erosion (Onda and Yukawa, 1995). Infiltration rate is one of the most important parameters in the rainfall runoff process (Dung et al., 2017). Characteristics of the infiltration process will directly affect the generation of flow processes such as surface runoff, subsurface flow and groundwater flow (Dunne, 1991; Hiraoka et al., 2010). In the area where soil has really high infiltration capacity, there is almost non-existent of surface flow (Horton, 1993). On the contrary, soil with low infiltration might lead to the large amount of infiltration excess runoffs, in that case, the high amount of eroded soil is swept away as a result (Horton, 1993). From that fact, maintaining soil infiltration is important for reducing the degradation of the soil and water resources.

The infiltration process is affected by many different factors such as precipitation characteristics, soil property, and topography. Among other factors, plant cover has been emphasized as the one which significantly affects the penetration of water (Hiraoka et al., 2010). Runoff and soil infiltration are important determinants of vegetation patterns (Dune et al., 1991), but vegetation patterns also 
modify the infiltration capacity directly (Hiraoka et al., 2010). Vegetation control infiltration rate through vegetation cover, root development, organic content (Dune et al, 1991). Vegetation or mulches protect the soil surface from the effects of rain drops, which directly cause the surface sealing and crusting (Kinnell, 2005). Otherwise, the long and large root systems penetrate the soil and increase its porosity. Organic matter from plants promotes a crumbly structure by improving the permeability of the soil. In general, soil with high vegetation cover has high infiltration rate (Hiraoka et al., 2010). The loss of understory vegetation can reduce infiltration capacity of soil and lead to some serious problems such as Horton overland flow and soil erosion (Dung et al., 2015; Linh et al., 2018).

Nowadays, the large area of natural forest has been replaced by planted forest due to the high demand in economic development. However, it should be noted that the ability to regulate water is varied at different forest cover types. The reasons might be attributable to the inappropriate forest practices and the natural characteristic of the vegetation cover (Dung et al., 2017; Linh et al., 2018). Monoculture plantations with different properties might have the complicated impact on the soil infiltration rate. Soil under planted forest is often compacted, has low porosity and low understory vegetation cover due to the impact of machines, which have been used in the process of forest management activities. Some unmanaged plantation with high stand density also has the result in little percent of ground cover (Dung et al., 2011; Shinohara et al., 2019). Furthermore, some plant species are believed to have the distinct effect on soil properties, which directly determine the infiltration process. For instance, some hypothesis proposed that the oil of Eucalyptus tree makes the upper soil layer drier and understory vegetation cannot grow, therefore it reduces the infiltration rate (Dung et al., 2017). Pine tree was found to have negative impact on the nutrient accumulation process of soils (David, 1982). On the other hand, the acacia tree, which belongs to Fabaceae family, is believed to have nitrate fixation ability and make the soil become better (May and Attiwill, 2003). The information on how different plantations with varied soil properties and understory vegetation cover determine the soil infiltration characteristics should be clarified.
In Vietnam, about 24\% of the forest area is planted forest, in which acacia and pine are the two most widely grown species for various purposes such as timber, firewood, agroforestry, land improvement (Hoan, 2014). Beside this, both species can be planted on bare land, bare hills, degraded, poor, and arid soils. For all the benefits that acacia and pine plantations bring back to local people, the area of these forests is expected to increase in the future (Ministry of Agriculture and Rural Development, 2012). Thus, the soil infiltration characteristics under two tree species in process of forming overland flow and erosion should be well understood for the development of sustainable plantation models.

Research on soil infiltration under different land uses was previously conducted worldwide (Dune et al., 1991; Haws et al., 2004 and Hiraoka et al., 2010) but is still limited in Vietnam (Dung, et al., 2015 and Dung, 2016), especially in planted forest. On the other hand, the characterization of spatial soil infiltration is a new research field that has been of interest in the recent years for the purpose of detecting the movement of water within the soil (Chyba et al, 2013). Dye tracer experiments supply qualitative pictures to illustrate the flow pathways in soil and provide deeper understanding on flow processes in soil (Alaoui, 2008).

\section{Study site and methods}

\subsection{Study site}

This study was conducted in acacia (Acacia mangium) and pine (Pinus merkusii) planted forests that are located in Dong Xa commune, Van Don district, Quang Ninh province of Vietnam (Figure 1). Dong Xa commune stretches over approximately $77.1 \mathrm{~km}^{2}$ and is characterized by a tropical monsoon climate. The rainfall regime is influenced by north-eastern monsoons. The average annual rainfall varies between 1700-2400 mm, with rainfall concentrated in the summer months for 90-170 days, particularly in July and August. The average relative humidity ranges from 80 to $86 \%$ and the mean annual temperature is approximately $23^{\circ} \mathrm{C}$. The soil type in this area is defined as Feralit soil. 


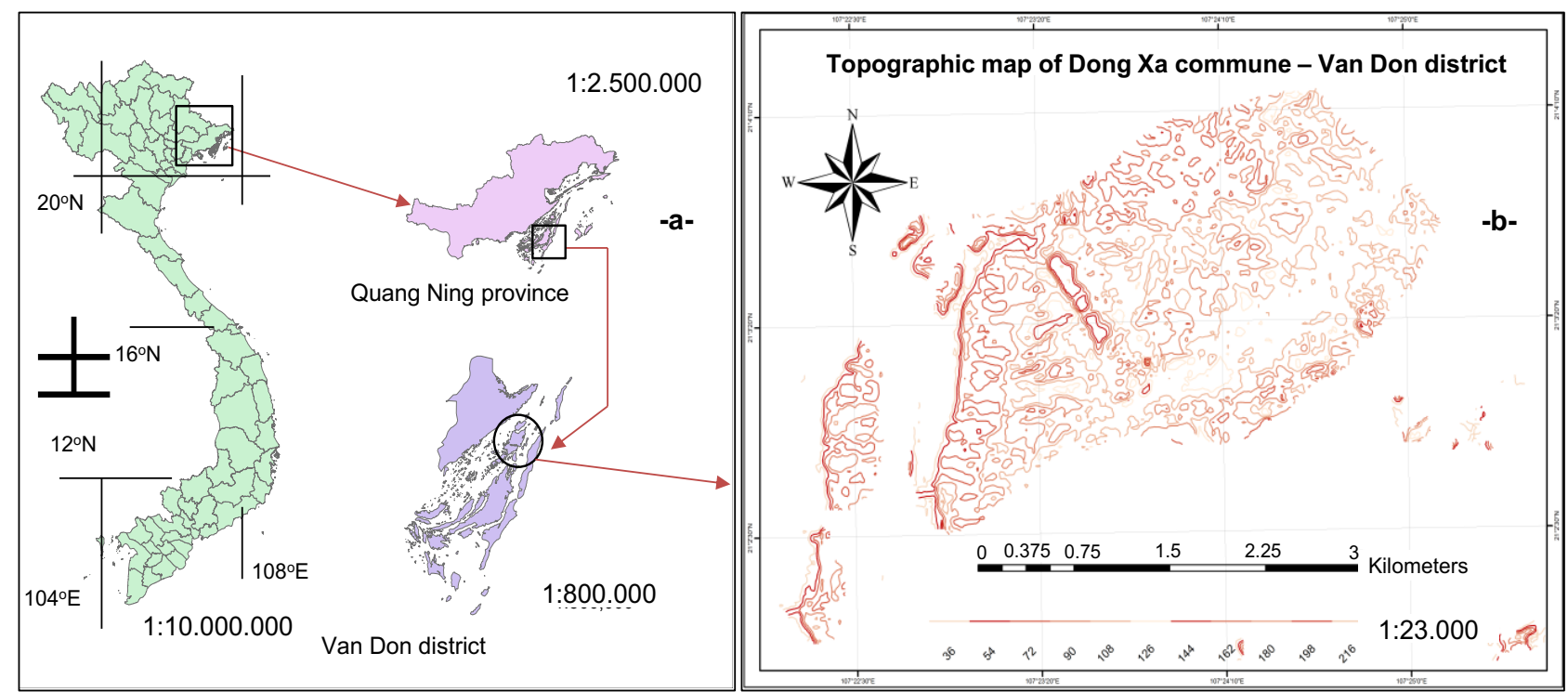

Figure 1. a) The location and b) topography map of the study site

\subsection{Methods}

\subsubsection{Field experiment for infiltration measurement}

a. Temporal infiltration characteristics measurement
Infiltration measurements were conducted at 5 locations in the uphill part, 5 locations in the middle hill part and 5 locations in the downhill part in each kind of planted forest (Figure 2). The monitoring period was from June to August, 2018.

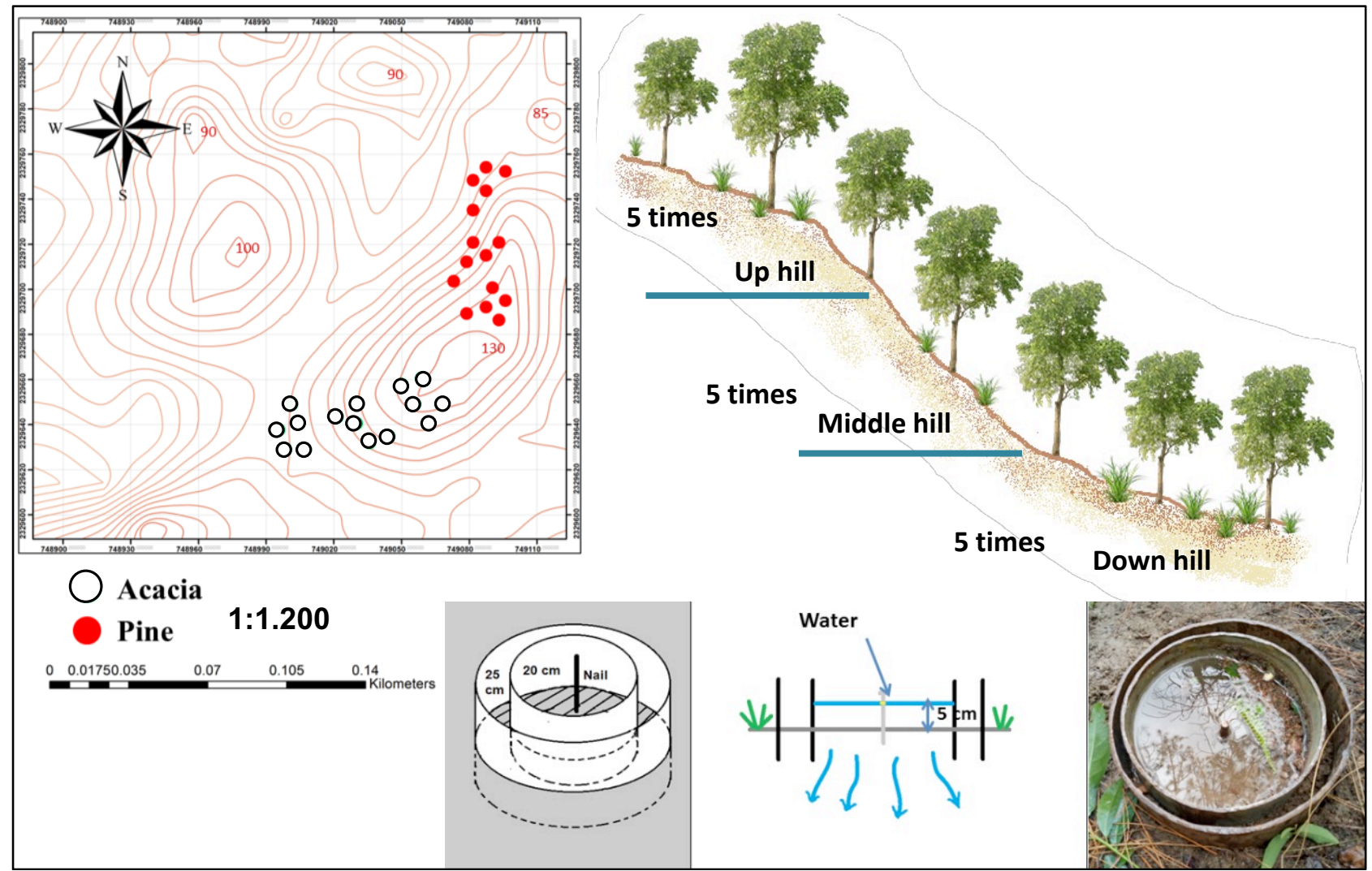

Figure 2. Location and the method used to measure soil infiltration at the study site

The metal double-ring infiltrometer was used to measure the infiltration rate following Dung et al., 2017; Linh et al., 2018.. The height of both rings is $15 \mathrm{~cm}$, the diameter of the inner and outer rings is $20 \mathrm{~cm}$ and $25 \mathrm{~cm}$, respectively. Firstly, a wooden piece was put across the rings then a hammer was used to drive the rings $5 \mathrm{~cm}$ into the ground. The aim of using wooden piece was to protect the rings from damage during hammering, and by using hammer, the cylinder rings were dug inside the soil without making any disturbance in the soil surface. Secondly, a nail was 
plugged into the ground at the center of the ring, and kept $5 \mathrm{~cm}$ above the ground. In the third step, a cylinder was used to pour the water slowly into the inner ring. In general, the water level was kept at $5 \mathrm{~cm}$ above the topsoil (when the water infiltrated downward and the water level inside the inner ring was lower than the top of the nail, then more water was added). The amount of water infiltrated was recorded every 5 minutes. When the level of the infiltrated water did not change anymore $(<2 \%)$, the experiment was terminated (Figure 2)

In term of impacting factors, at each location where infiltration rate was monitored, understory vegetation cover and soil properties were also assessed (Table 1). The pictures of the underground vegetation cover were taken (standing in the central spot of each plot) and processed by using the using Canopy Cover Free application version
1.03 for Android. For soil properties measurement, soil samples were taken by using a bulk density tube. The tube was gently hammered into the soil, then it was taken up carefully to make sure that the soil it contained was not disturbed. The soil and the plant root from outside the ring was removed, then the soil sample inside the tube was poured into a sealed plastic bag and analysed in laboratory to determine dry bulk density, porosity, and soil moisture. After finishing all the field measurements, R-studio software, version 3. 5. 1, 32 bit (www.rstudio.com) was used to process data in order to find the correlation between the infiltration rate and other factors. The same software was also used for checking the median and the outlier range of data as well as for analysing the independent sample t-test to find out if there was the statistically different in the data for two plantations.

Table 1. Soil properties and underground cover at each location

\begin{tabular}{c|cccc|cccc}
\hline & \multicolumn{7}{|c|}{ Pine plantation } & \multicolumn{4}{c}{ Acacia plantation } \\
Location & $\begin{array}{c}\text { Bulk density } \\
\left(\mathrm{g} / \mathrm{cm}^{3}\right)\end{array}$ & $\begin{array}{c}\text { Porosity } \\
(\%)\end{array}$ & $\begin{array}{c}\text { Underground } \\
\text { cover }(\%)\end{array}$ & $\begin{array}{c}\text { Soil moisture } \\
(\%)\end{array}$ & $\begin{array}{c}\text { Bulk density } \\
\left(\mathrm{g} / \mathrm{cm}^{3}\right)\end{array}$ & $\begin{array}{c}\text { Porosity } \\
(\%)\end{array}$ & $\begin{array}{c}\text { Underground } \\
\text { cover }(\%)\end{array}$ & $\begin{array}{c}\text { Soil moisture } \\
(\%)\end{array}$ \\
\hline 1 & 1.35 & 49.03 & 26.10 & 31.23 & 1.17 & 55.96 & 16.10 & 22.31 \\
2 & 1.38 & 48.05 & 4.30 & 28.01 & 1.15 & 56.74 & 30.20 & 13.45 \\
3 & 1.21 & 54.38 & 13.80 & 26.91 & 1.30 & 50.86 & 49.30 & 12.10 \\
4 & 1.32 & 50.17 & 18.60 & 27.87 & 0.97 & 63.53 & 21.40 & 31.12 \\
5 & 1.41 & 46.69 & 17.10 & 26.40 & 0.93 & 64.78 & 27.30 & 14.17 \\
6 & 1.42 & 46.26 & 10.20 & 25.50 & 1.14 & 56.89 & 21.60 & 21.37 \\
7 & 1.38 & 47.87 & 0.00 & 11.26 & 1.18 & 55.53 & 25.20 & 20.43 \\
8 & 1.45 & 45.25 & 11.90 & 19.12 & 1.03 & 61.13 & 13.40 & 22.99 \\
9 & 1.16 & 56.14 & 16.30 & 35.21 & 1.09 & 58.93 & 10.00 & 28.00 \\
10 & 1.39 & 47.36 & 27.50 & 22.73 & 1.00 & 62.17 & 11.90 & 24.80 \\
11 & 1.23 & 53.69 & 9.20 & 10.20 & 0.97 & 63.50 & 73.70 & 13.26 \\
12 & 1.16 & 56.11 & 36.40 & 15.41 & 1.04 & 60.84 & 45.30 & 24.55 \\
13 & 1.15 & 56.74 & 54.70 & 13.58 & 1.16 & 56.17 & 36.80 & 19.53 \\
14 & 1.13 & 57.54 & 65.50 & 16.70 & 1.05 & 60.36 & 38.10 & 23.76 \\
15 & 1.32 & 50.00 & 38.70 & 28.33 & 0.98 & 62.92 & 53.20 & 17.49 \\
\hline Min & 1.13 & 45.25 & 0.00 & 10.20 & 0.93 & 50.86 & 10.00 & 12.10 \\
Max & 1.45 & 57.54 & 65.50 & 35.21 & 1.30 & 64.78 & 73.70 & 31.12 \\
Mean & 1.30 & 51.02 & 23.35 & 22.56 & 1.08 & 59.35 & 31.57 & 20.62 \\
\hline DD & 0.11 & 4.15 & 17.90 & 7.43 & 0.10 & 3.77 & 17.32 & 5.46 \\
\hline
\end{tabular}

\section{b. Spatial infiltration characteristics measurement}

To check the spatial infiltration distribution of water into soil, a dye tracer experiment provided qualitative pictures illustrating the flow pathways and the hydrodynamic aspects of flow processes in the soil (Haw et al., 2004). The dye tracer experiment was conducted at three plots with similar slope, elevation, and soil properties. The first plot was selected under the acacia trees, the second plot was located under the pine trees and the third plot was soil without trees (Figure 3). The experiment was carried out over a two-day period. 150 grams of dye were dissolved with 60 liters of water and then divided into three budgets. On the first day, dye was poured to the three plots and all characteristics of the two areas, such as slope, plantation floor, and canopy cover were recorded (Table 2).

On the second day, four layers of soil were dug in $10 \mathrm{~cm}$ space between layers and $1 \mathrm{~m}$ deep for each layer to observe the motion of the dye. First, the outermost layer was dug first (the last point). The outer layer was dug 40 $\mathrm{cm}$ away from the dye. With four layers to be dug, each layer was $10 \mathrm{~cm}$ closer to the end point. Photo snapshots were taken of each layer for analysis. The steps above were repeated for the other plots (Figure 3). The pictures of each layer was analysed by Maplnfo software to calculate the depth and area of dye on each layer (Figure 4). 
Table 2. Characteristics of dye tracer experiment plots

\begin{tabular}{lccc}
\hline Parameter & Plot with no trees & Plot with acacia trees & Plot with pine trees \\
\hline Slope $\left(^{\circ}\right)$ & 10 & 12 & 13 \\
Understory vegetation cover $(\%)$ & 31.00 & 11.90 & 10.20 \\
DBH $(\mathrm{cm})$ & - & 18 & 27 \\
Height of tree $(\mathrm{m})$ & - & 10 & 19 \\
Age of tree (year) & - & 7 & 20 \\
\hline
\end{tabular}

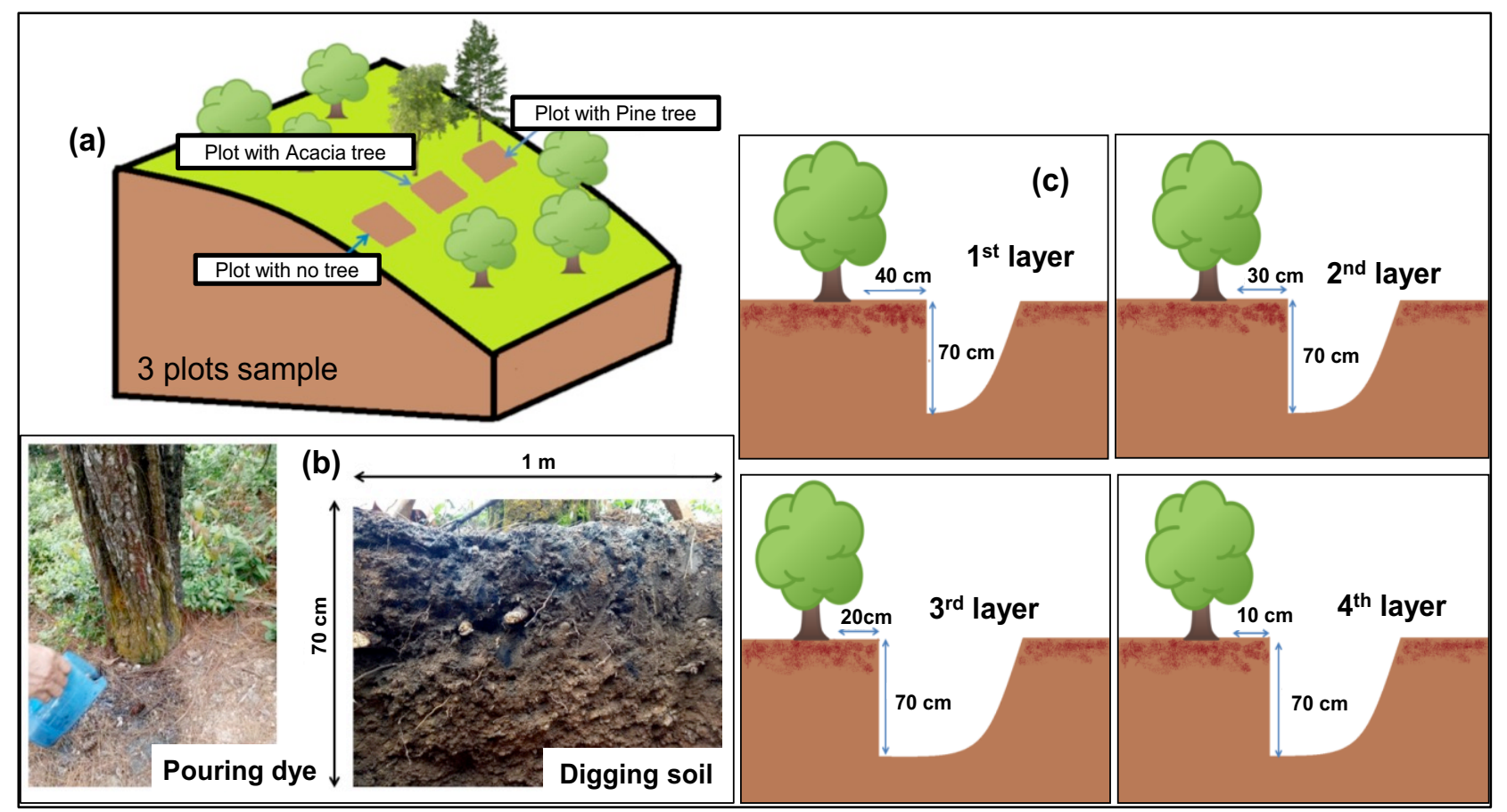

Figure 3. Spatial infiltration measurement using dye tracer: (a) location of plots; (b) Pouring dye and digging soil; (c) Illustration for four layers dug

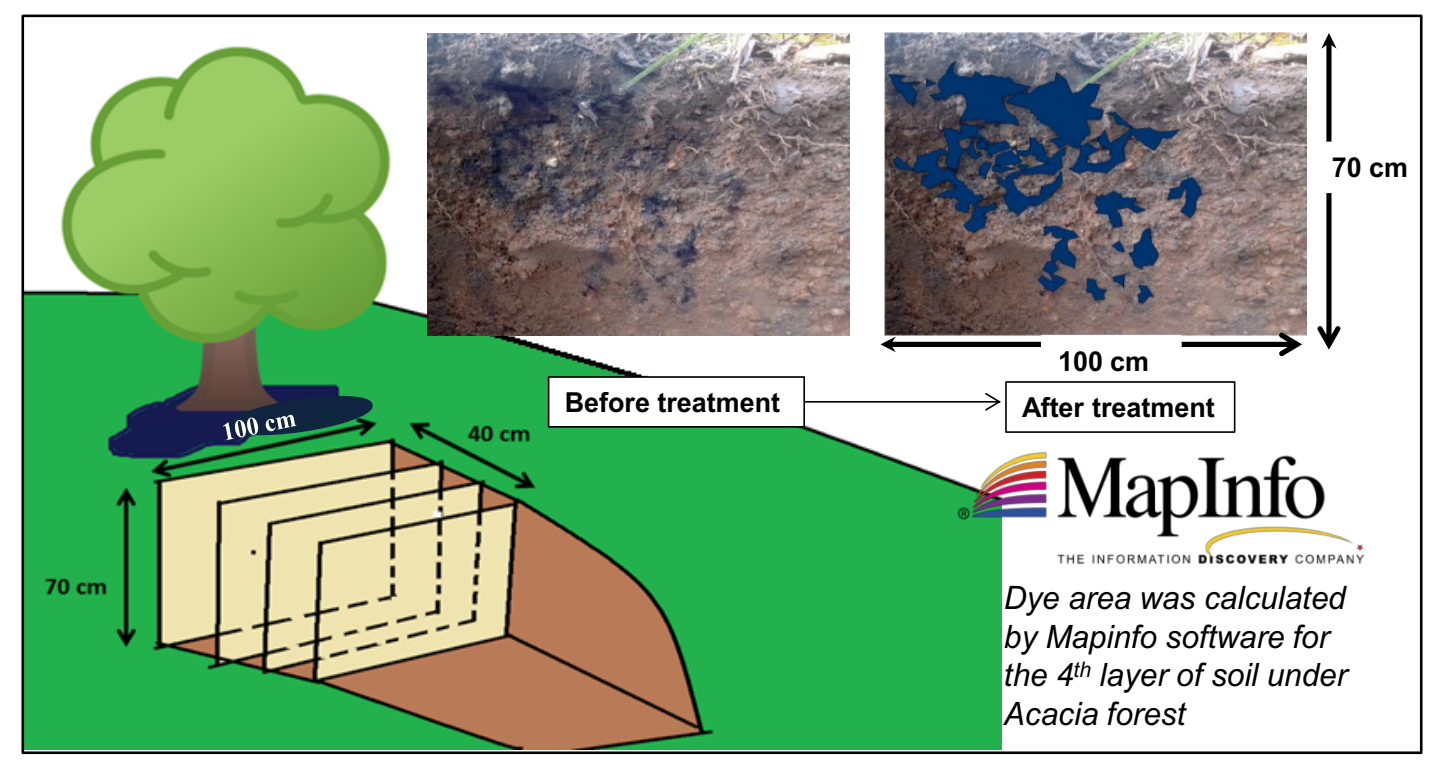

Figure 4. Illustration graph to explain the way to calculate dye area by MapInfo.

\section{Results and discussion}

\subsection{Temporal soil infiltration characteristics}

3.1.1. Soil infiltration rates under pine and acacia plantations
The soil infiltration rate was inconsistent. The infiltration rate tended to be decrease over time in both planted forests at different locations. The initial infiltration rate was the highest, it ranged from 6.9 to $39.6 \mathrm{~mm} / 5 \mathrm{~min}$, averaged $13.8 \pm 8.9 \mathrm{~mm} / 5 \mathrm{~min}$ in the pine plantation, while that of 
acacia plantation ranged from 9.1 to $37.6 \mathrm{~mm} / 5 \mathrm{~min}$, averaged $15.9 \pm 8.4 \mathrm{~mm} / 5 \mathrm{~min}$ (Figure 5). The stable infiltration rate was the smallest in both planted forests. The range of stable infiltration rate in the pine plantation was 0.5-6.3 mm/5 min, averaged $2 \pm 1.4 \mathrm{~mm} / 5 \mathrm{~min}$, while that of acacia plantation ranged 2.5-7.3, averaged $3.8 \pm 1.3$ $\mathrm{mm} / 5 \mathrm{~min}$ (Figure 5). The infiltration rate at all the measuring locations decreased significantly after 60 minutes. After 80 minutes, the infiltration rate changed but not significantly. During 100 minutes, the infiltration rate stayed stable in both planted forests as water replaced the air in the pores. The water from the soil surface infiltrated slower but eventually reached a steady rate (Figure 5).
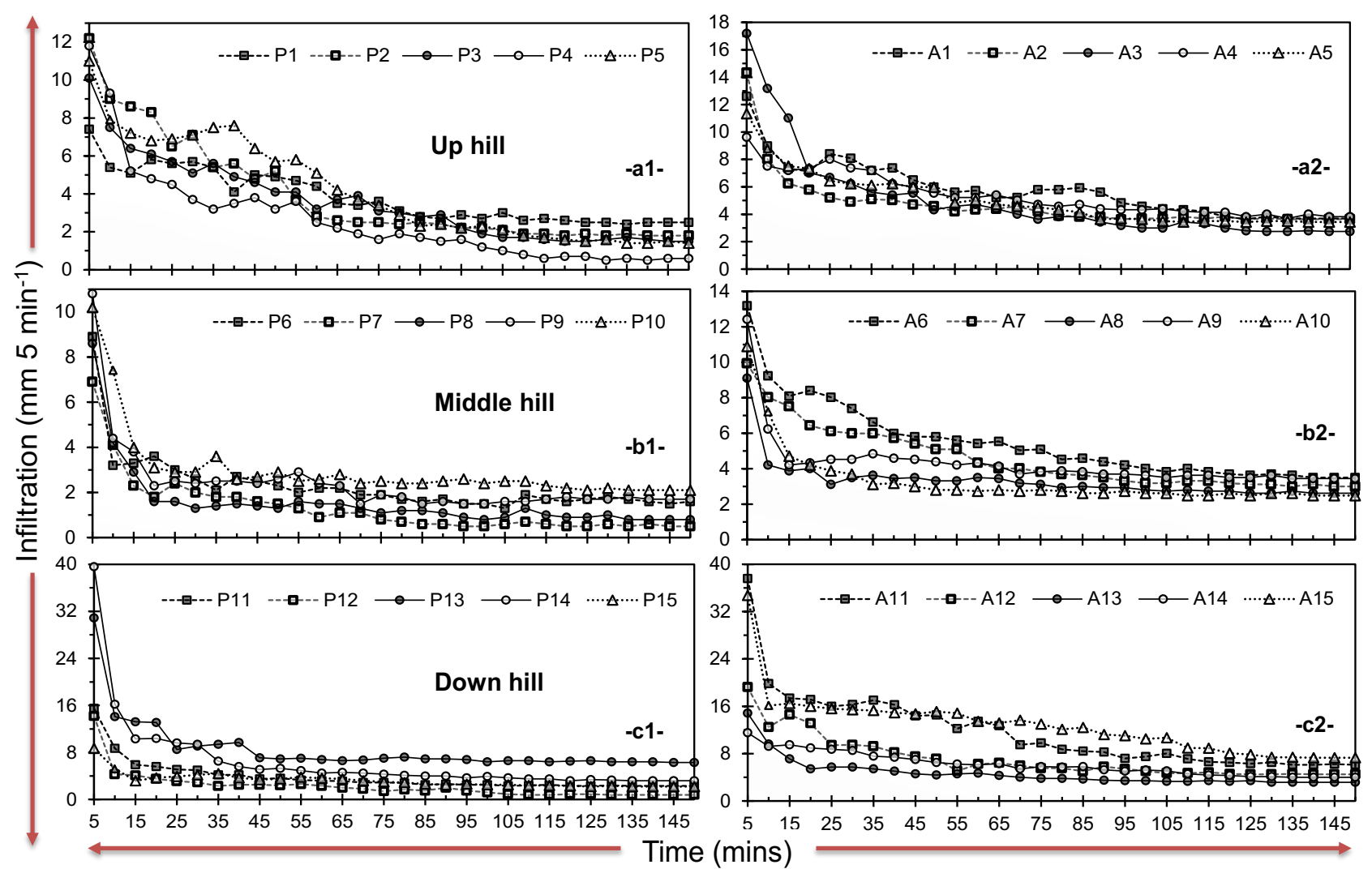

Figure 5. Temporal infiltration characteristics of soil under pine plantation (a1-c1) and acacia plantation (a2-c2) at different locations

Infiltration rate in both pine and acacia plantations were the highest at downhill $(21.8-23.6 \mathrm{~mm} / 5 \mathrm{~min}$ of initial infiltration and 3-5 mm/5 min of stable infiltration). Meanwhile, all five monitoring locations at top hill had smaller infiltration rates $(10.5-13.0 \mathrm{~mm} / 5 \mathrm{~min}$ of initial infiltration and 1.6-3.5 mm/5 min of stable infiltration). The lowest value of infiltration rates were found at middle hill (9.1-11.1 mm/5 min of initial infiltration and 1.3-3.0 mm/5 min of stable infiltration) (Figure 6). The main reason was that the bottom part of the pine and acacia hill had gentler slope and higher vegetation cover, resulting in sediment associated with flows usually accumulating in this part. Thus, in the middle and top parts of the acacia plantation overland flow and erosion are more likely to occur than at the bottom hill (Figure 6).

The initial infiltration rates and the stable soil infiltration rates under pine and acacia plantations presented less variability (Figure 7). The infiltration rate of the acacia plantation was higher than that of pine at different locations. The initial soil infiltration rate under acacia plantation (mean value: $16 \mathrm{~mm} / 5 \mathrm{~min}$ and median value: 13 $\mathrm{mm} / 5 \mathrm{~min}$ ) was higher than the ones of soil under pine plantation (mean: 14 and median: 11 mm/5min). However, according to the result of independent samples t-test, there was no statistical significant different between them with $p$-value $=0.52$ (Figure 7 ). The stable soil infiltration rate under acacia planted forest (mean: 3.8 and median: 3.5 $\mathrm{mm} / 5 \mathrm{~min}$ ) was higher than that of soil under pine planted forest (mean: 2 and median: $1.7 \mathrm{~mm} / 5 \mathrm{~min})$. This difference was statistical significant with $p$-value $=0.00$ (Figure 7). The potential reason might be due to leaves and branches of pine that had somehow negative impacts to the soil in nutrient accumulation processes (David, 1982). In contrast, the leaf litters of Acacia mangium were found to be important to the ecosystem for providing a source of nutrient and the boosting factor of the microorganism's diversity (Samingan and Sudirman, 2009; Inagaki et al. 2011). Soils under a variety of tree species of acacia are often higher in nitrogen, phosphorus and other nutrients (Santos et al., 2017) and acacia litter greatly contributed to soil fertility due to the tree's ability to fix atmospheric nitrogen (Dowling et al., 1986). Another research of Mugunga and Mugumo (2013) about the effects of acacia species in Songa pasture, Rwanda, also found out that soil under acacia tree canopy was significantly richer in $\mathrm{N}$ as compared to grasses. Hence, the notion that acacia trees could improve the soil was somehow appropriate. 
Moreover, the result of this research also indicated that the soil under the canopy of Pine trees has less vegetation cover and also has lower porosity. Since the stable infiltration rate tends to have a positive relationship with porosity of soil (Dung, 2016), that might be the reason why the stable infiltration rate at acacia plantation was higher than that at the pine plantation.
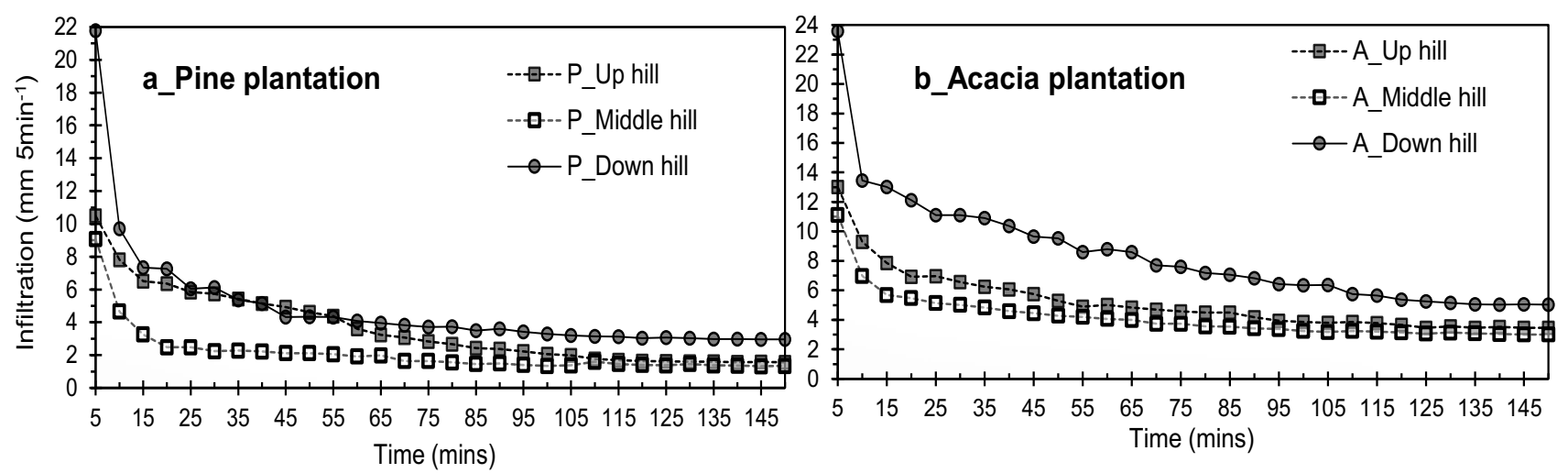

Figure 6. Temporal soil infiltration characteristics under (a) pine plantation and (b) acacia plantation

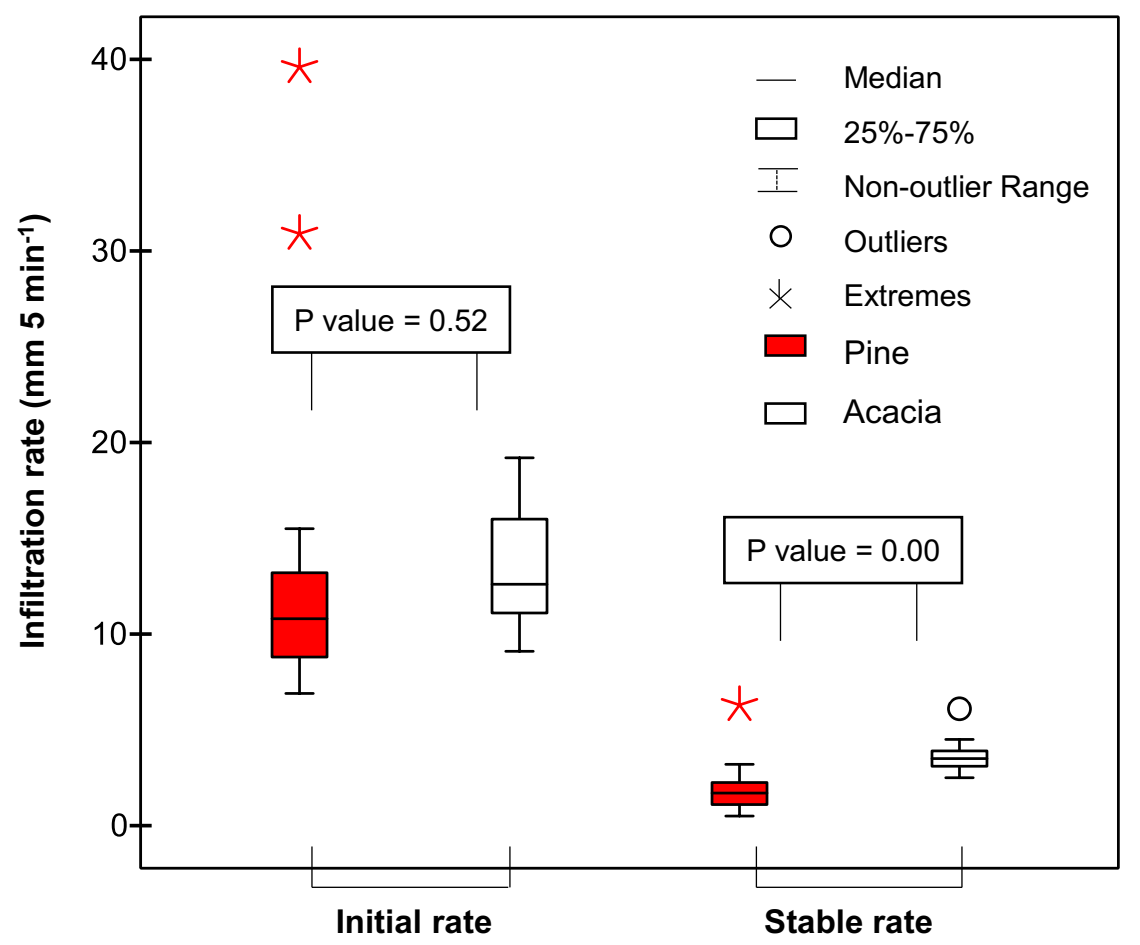

Figure 7. Box-plot results of initial rate and stable rate under pine and acacia planted forests. The length of the box represents the sample interquartile range, the cross bar in the box the sample median, the notch its $95 \%$ interval and the circles the outlying data points defined as being larger than 1.5 times the interquartile range.

3.1.2 Total water infiltrated in one hour at different plantations

The amount of water infiltrated in one hour at the acacia planted forest was significantly higher than the one recorded at the pine planted forest (Figure 8): in average
$486 \mathrm{~mm}$ and $323 \mathrm{~mm}$, respectively. At both plantations, the highest amount of water infiltrated in one hour belonged to the down-hill part, while middle-hill part accounted for the lowest one (Figure 8). The high amount of water infiltrated in one hour indicated that the chance for overland flows is lower. 

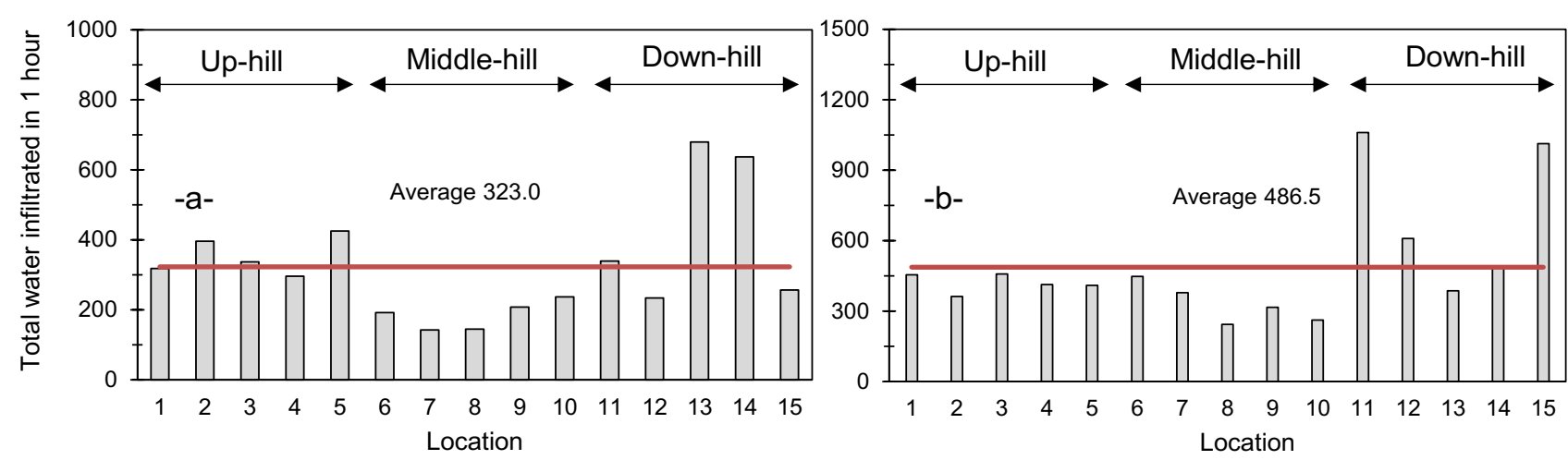

Figure 8. The amount of total water infiltrated in one hour at different locations of (a) pine planted forest; (b) acacia planted forest.

Comparing with the total water infiltrated in one hour reported by other researches at different locations, the amount of water in the acacia plantation was within previous findings from 59-809 mm/hr, averaged 367 $\mathrm{mm} / \mathrm{hr}$. In previous studies, the hourly infiltration rate under pine plantation was within 302-434 mm (Figure 9). The quite high amount of water infiltrated in one hour of this study might be explained by the high porosity and understory vegetation cover (Table 1). Previous researches

have proved that the increase in porosity and ground cover would lead to the increase in infiltration capacity and the decrease in the amount of infiltration excess overland flow (Weiler, 2006; Hiraoka et al., 2010). The total water infiltrated in one hour is linked to the probability of overland flow during storms (Linh et al., 2018). With high amounts of water infiltrated in one hour, the soil under these pine and acacia plantations are expected to induce little amount of saturated overland flow.

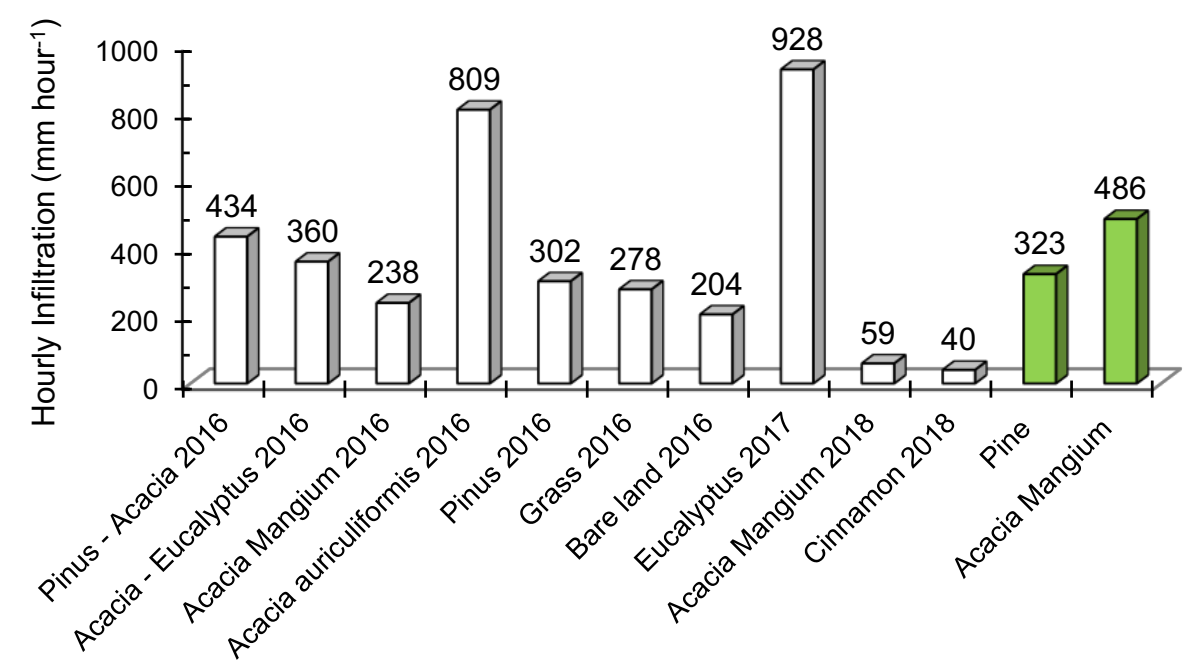

Figure 9. Comparing total water infiltrated in one hour of soil under pine and acacia plantations from this study (green bars) with ones from other the previous studies ([Dung, 2016 and Dung et al., 2017 [research in Xuan Mai town, Hanoi city]; and Linh et al., 2018 [Research in Van Yen district, Yen Bai province]).

\subsection{Spatial soil infiltration characteristics} under pine and acacia plantations and bare soil.

The area and the depth of infiltrated water was different among soil without trees, with acacia and with pine trees (Figure 10 and 11). The area and depth of infiltrated dye were the highest at the plot of soil without trees, smaller at the plot of soil with acacia trees and the smallest at the pine plot (Figure 10 and 11). In particular, there was no evidence of infiltrated water in all cases at the first layer (40 $\mathrm{cm}$ far from dye pouring). The depth of infiltrated dye at the plot without trees was increased from the $2^{\text {nd }}$ layer to the $4^{\text {th }}$ layer of soil at $26 \mathrm{~cm}, 58 \mathrm{~cm}$ and $60 \mathrm{~cm}$, respectively. At the plot with acacia trees, the depth of infiltrated dye at the $2^{\text {nd }}$ layer, the $3^{\text {rd }}$ layer and the $4^{\text {th }}$ layer in turn was 18 $\mathrm{cm}, 25 \mathrm{~cm}$ and $35 \mathrm{~cm}$, while at the plot with pine trees, they were $20 \mathrm{~cm}, 20 \mathrm{~cm}$ and $29 \mathrm{~cm}$, respectively. The area of dye infiltrated into the soil was $46 \mathrm{~cm}^{2}$ at the $2^{\text {nd }}$ layer to 1014 $\mathrm{cm}^{2}$ at the $3^{\text {rd }}$ layer and $1452 \mathrm{~cm}^{2}$ at the $4^{\text {th }}$ layer for plot without tree. This value at the plot with acacia tree was 26 $\mathrm{cm}^{2}, 451 \mathrm{~cm}^{2}$ and $1286 \mathrm{~cm}^{2}$ at the $2^{\text {nd }}$, the $3^{\text {rd }}$ and the $4^{\text {th }}$ layer of soil, respectively. The plot with pine trees had the smallest infiltrated area of dye at $14 \mathrm{~cm}^{2}, 75 \mathrm{~cm}^{2}$ and 527 $\mathrm{cm}^{2}$ from $2^{\text {nd }}$ to $4^{\text {th }}$ layer, respectively. 


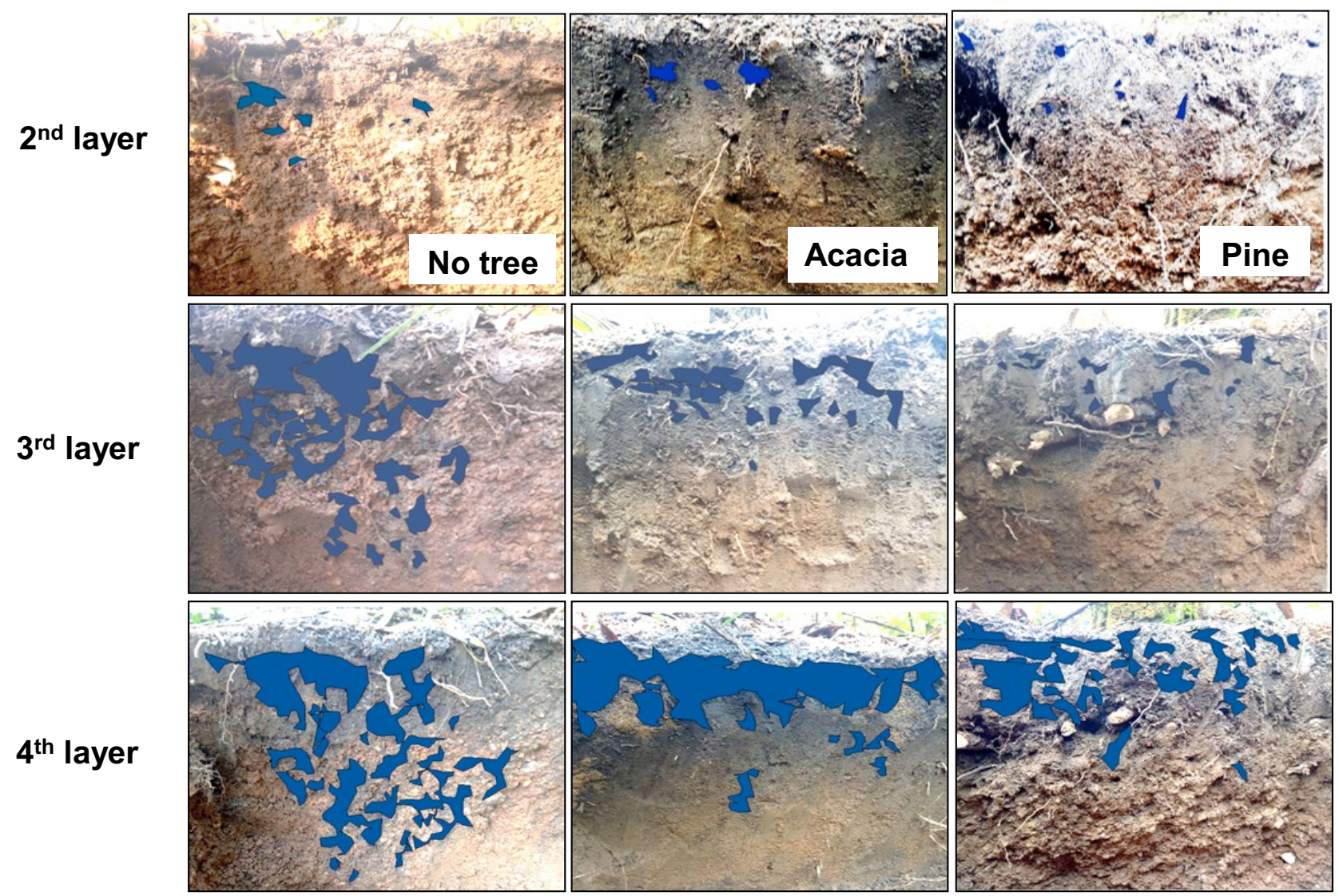

Figure 10. Spatial infiltration of soil under plot without tree, acacia plot and pine plot at the study site
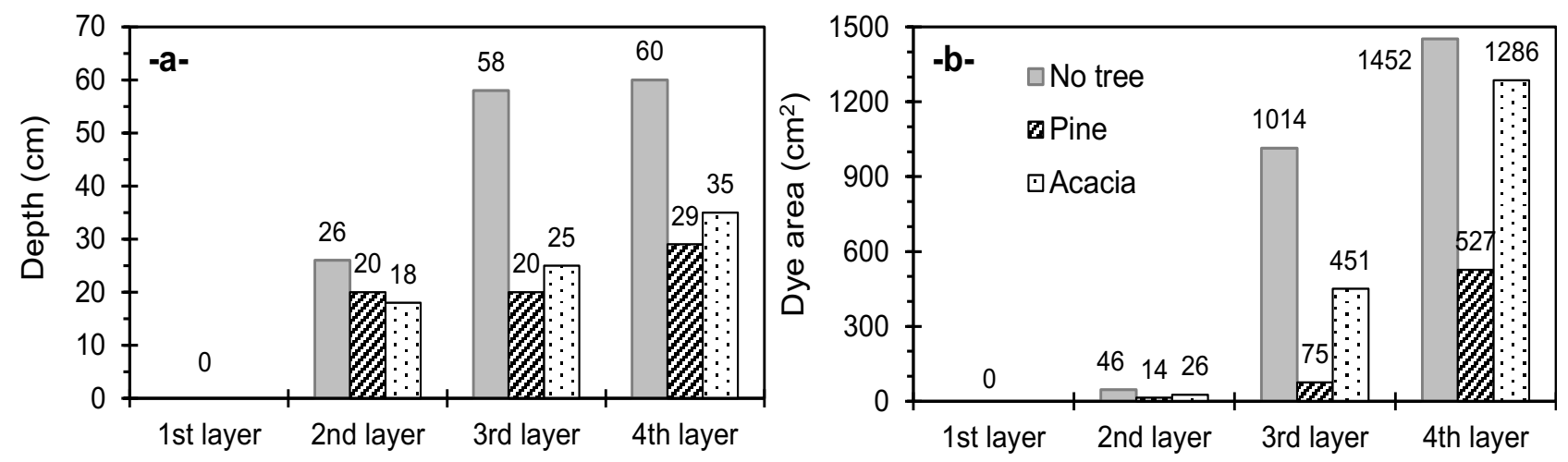

Figure 11. Spatial infiltration of soil under plot without trees, acacia plot and pine plot: a- infiltrated depth and b- infiltrated area at the study site 


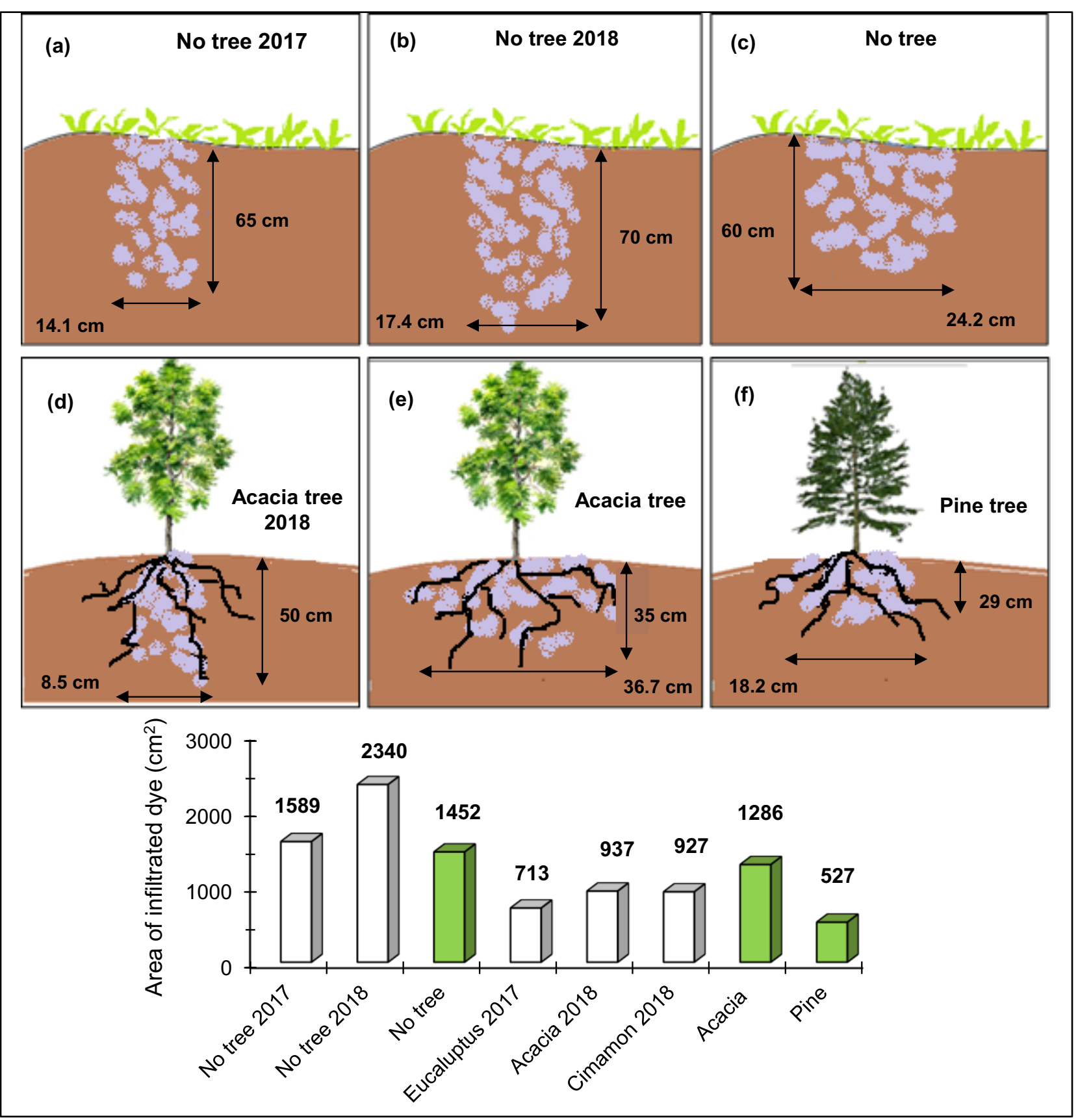

Figure 12. Spatial infiltration of soil of this study (green bars) comparing to the previous studies: (a) adopted from Dung et al. (2017) and (b) \& (d) adopted from Linh et al. (2018).

In general, dye tended to infiltrate deeper and higher area at the plot without trees. While it had the tendency to concentrate around the root system at the plot with trees (Figure 10, 11 and 12). This result might be attributable to the water uptake by the tree root for the photosynthesis and evapotranspiration processes. Otherwise, because of the polar nature of water, it adhered to the xylem cell walls and the hydrogen bonds keep the molecules held together (cohesion) in a continuum. Most of the water stays at the upper part where the root system is dense with tap roots and lateral roots, then it is absorbed by the tree root (Gardner, 1964). That might explain why the infiltrated water cannot go to deeper and larger area at the plots with tree growth. Previous researches using dye tracer experiment under eucalyptus, acacia and cinnamon planted forests also showed that dyes tend to infiltrate deeper in the plot without tree $60 \mathrm{~cm}-70 \mathrm{~cm}$, averaged $65 \mathrm{~cm}$ of infiltrated water depth and $1589 \mathrm{~cm}^{2}-2512 \mathrm{~cm}^{2}$, averaged $2147 \mathrm{~cm}^{2}$ of total infiltrated water area) compare to the plot with tree $(29 \mathrm{~cm}-50 \mathrm{~cm}$, averaged $38 \mathrm{~cm}$ of infiltrated water depth and $616 \mathrm{~cm}^{2}-1763 \mathrm{~cm}^{2}$, averaged $991 \mathrm{~cm}^{2}$ of total infiltrated water area) (Figure 12).

The results also showed that the depth and the area of infiltrated dye at the plot with acacia trees were greater than that at the plot with pine tree. This might be explained by the fact that the diameter at breast high (DBH) and the height of acacia trees were smaller than those of the pine trees (Table 1), hence the demand for water uptake of this tree was lower and water could infiltrate deeper and wider into the soil. Besides, as we have already mentioned above, both the root and the litter of acacia tree has the ability to 
enhance the fertility of the soil and to increase a diversity of microorganisms, so the soil porosity under acacia trees might be higher. The soil with bigger pores so the water can easily percolate down by gravity, in contrast, in the small pore, the capillary force tends to boost water up. Weiler (2006) also argued about the positive relationship of infiltration rates and pores in the soil by using brilliant blue dye tracer experiment. The depth and the area of dye implied that the soil is good or bad. A research of Pagliai and Vignozzi (2004) about the relationship between porosity and soil quality proposed that a decrease of porosity is generally associated with an increase of penetration resistance. The pore shape and the size distribution were also strictly related to the chemical, biochemical and biological properties, such as the enzyme activity and the root growth.

\subsection{Relationship of infiltration rate with other factors}

The porosity and the understory vegetation cover of the soil under acacia plantation were higher than the ones of pine plantation while the soil moisture under acacia plantation was smaller than that of the pine plantation (Figure 13). In particular, the soil porosity under the pine and acacia plantations were quite high, ranging from 45.25 $\%$ to $57.54 \%$, averaged $51.02 \% \pm 4.15$. The standard deviation (SD) in the pine forest ranged from $50.86 \%$ to $64.78 \%$, averaged $59.35 \% \pm 3.77$ (SD) in acacia forest. The result of independent samples T-test indicated a statistically different between the porosity of the soil under the pine plantation and acacia plantation ( $p$-value $<0.05$ ). In the contrary, no statistically different was detected in the data for ground cover and soil moisture between the two plantations. The soil moisture of the pine plantation varied from $10.2 \%$ to $35.2 \%$, averaged $22.6 \% \pm 7.4$ (SD) (Table 1) while that of Acacia plantation was from $12.10 \%-31.12 \%$, averaged $20.62 \pm 5.46 \%$. The understory vegetation of the pine plantation tends to be smaller than the one of the acacia plantation. The values ranged from $0 \%$ to $65.5 \%$, averaged $23.4 \% \pm 17.9$ (SD) in pine plantation and from 10 $\%$ to $73.70 \%$, averaged $31.57 \% \pm 17.32$ (SD) in the acacia plantation (Figure 13, Table 1).

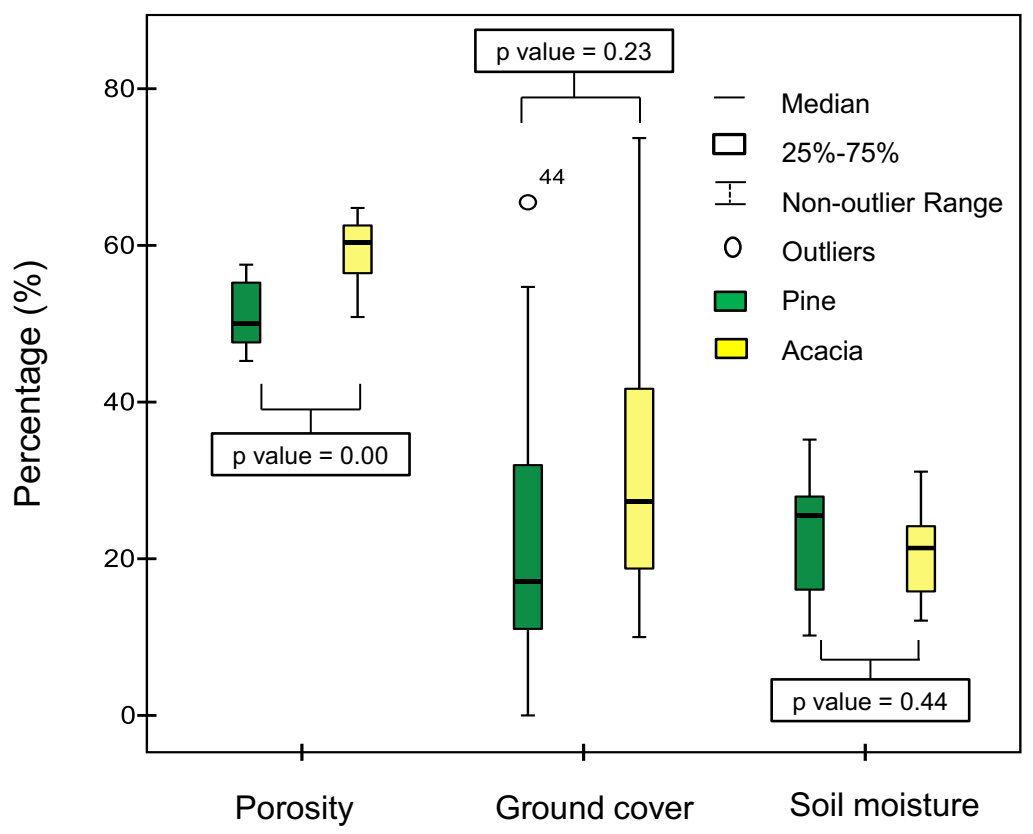

Figure 13. Box-plot results of porosity, understory vegetation and soil moisture under pine and acacia planted forests

Both the initial and stable soil infiltration rates under the pine and acacia plantation had a quite strong relationship with the understory vegetation cover (Figures 14 and 15). The correlation coefficient between the understory vegetation with the initial and stable rate in turn were 0.80 and 0.67 at the pine plantation (Figure 13) and $0.85-0.7$ at the acacia plantation (Figure 15). This result suggests that both initial and stable infiltration rates depend strongly on the understory vegetation cover. There was evidence that under the cover of vegetation, the accumulation of organic matter and the regulation of microclimate (Hiraoka et al.,
2010) were beneficial for the microbial activity and the formation of stable soil aggregates (Dune et al., 1991). The soil structure enhanced by these factors improves the infiltration. Typically, infiltration rates were often observed differently under different life forms (Horton, 1933). Recently, a number of studies have demonstrated the effectiveness of increasing the cover of ground floor plants, particularly grasses, reducing the runoff and erosion (Sharma et al., 1980). Therefore, with such a low underground vegetation cover in the pine and acacia plantations, erosion would easily occur. 


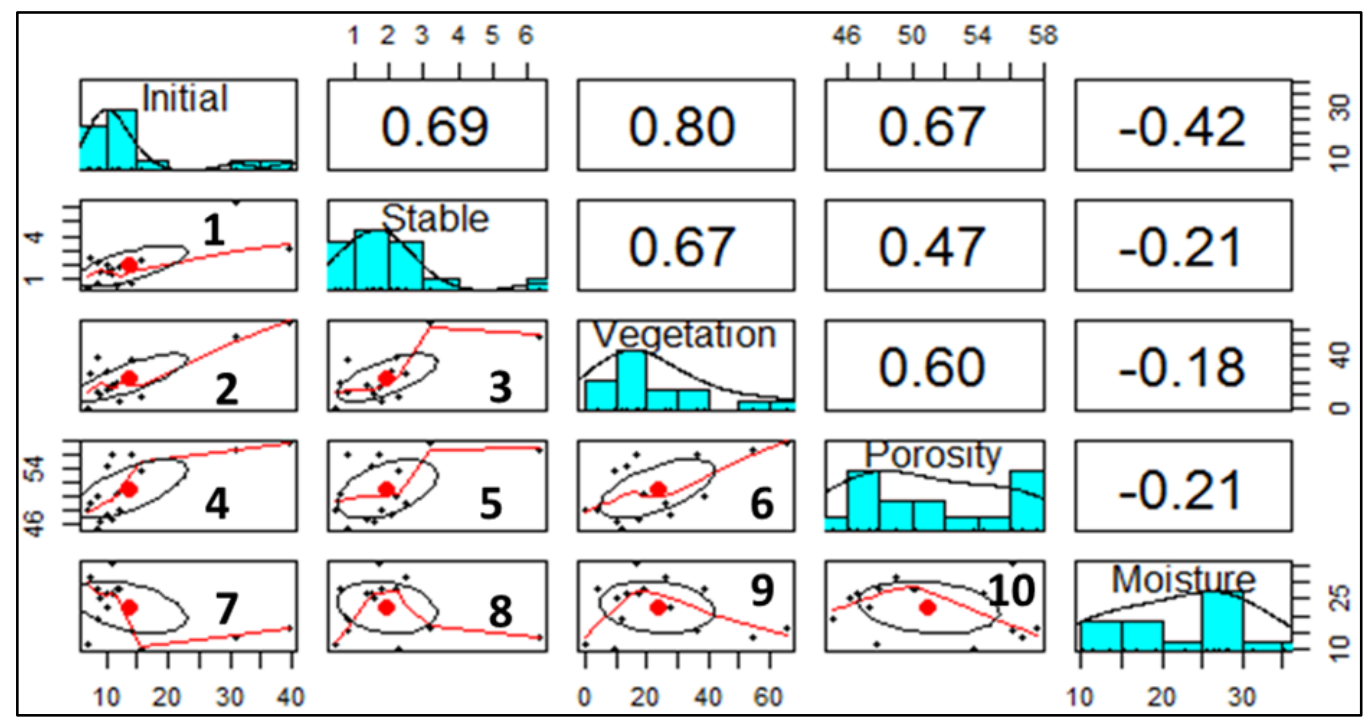

Figure 14. Pine planted forest - Correlation between: (1) Initial rate and stable rate; (2) Initial rate and vegetation cover; (3) Stable rate and vegetation cover; (4) Initial rate and porosity; (5) Stable rate and porosity; (6) Vegetation and porosity; (7) Initial rate and soil moisture; (8) Stable rate and soil moisture; (9) Vegetation and soil moisture; (10) Porosity and soil moisture.

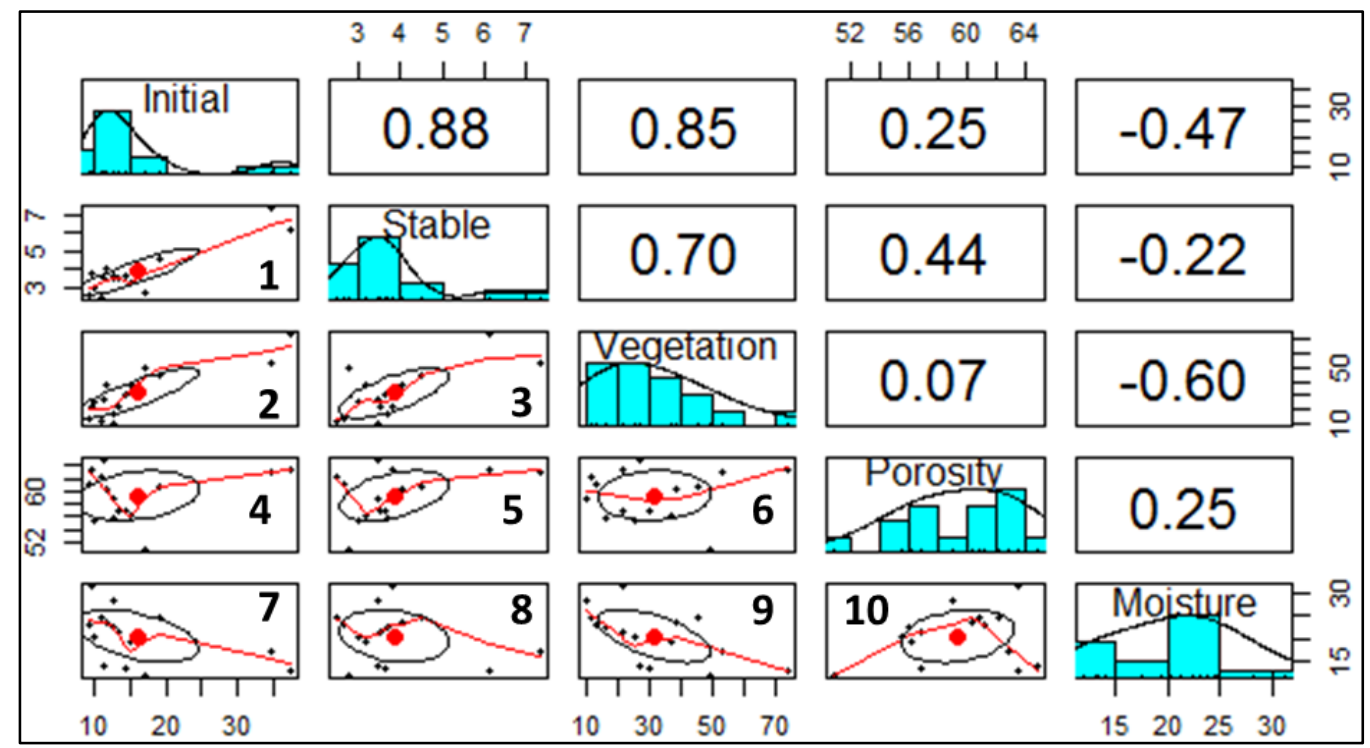

Figure 15. Acacia planted forest - Correlation between: (1)- Initial rate and stable rate; (2)- Initial rate and vegetation cover; (3) Stable rate and vegetation cover; (4) Initial rate and porosity; (5) Stable rate and porosity; (6) Vegetation and porosity; (7) Initial rate and soil moisture; (8) Stable rate and soil moisture; (9) Vegetation and soil moisture; (10) Porosity and soil moisture.

The initial soil infiltration rate under both pine and acacia planted forests had medium negative relationship with the soil moisture (correlation coefficient: -0.42 to -0.47 respectively). However, in the pine plantation, it had close relationship with porosity ( $r=0.67$; Figure 15). In contrast, it had weak relationship ( $r=0.25$ ) in acacia plantation (Figure 14). This contrast between plantations might be due to the difference of understory vegetation under the two plantations. Under acacia, the understory vegetation was higher, thus the initial infiltration rate was less dependent on the porosity and vice versa. Otherwise, it implied that there could be other factors affecting the initial rate in pine and acacia planted forest such as the moisture content of the topsoil and the mechanical components of the soil.
The stable soil infiltration rates under both pine and acacia plantations had moderate relationship with porosity (correlation coefficient: 0.47-0.44, respectively) and low relationship with soil moisture $(r=-0.21$ to -0.22 ) (Figures 14 and 15). This showed that the stable rate depended not only on the density and porosity, but also on other soil parameters such as the soil thickness, soil structure, and mechanical compositions (Dung, 2016).

\section{Conclusion}

For determining the temporal and spatial soil infiltration characteristics under the pine and acacia plantations, a double-ring infiltrometer was used to measure the temporal infiltration and dye tracer experiments were 
applied for spatial infiltration characteristics. In addition, software such as MapInfo, Microsoft Excel, and R-studio was used in analyzing data. The main findings include:

- $\quad$ The temporal soil infiltration rates under pine and acacia plantations tended to decrease over time at different location. The highest rate was recorded at the bottom of the hill and the lowest in the middle hill. The initial and stable infiltration rates of acacia planted forest is higher than that of pine planted forest. However, statistically significant difference was only found for the stable infiltration rate between the two plantations. In addition, the total amount of water infiltrated in one hour at the acacia plantation is higher than the ones of pine plantation $(486 \mathrm{~mm}$ $\mathrm{hr}^{-1}$ in acacia in comparison with $323 \mathrm{~mm} \mathrm{hr}^{-1}$ in the pine plantation);

- $\quad$ The area and the depth of infiltrated water was highest at the plot without trees $(60 \mathrm{~cm}$ of infiltrated water depth and $2512 \mathrm{~cm}^{2}$ of total infiltrated water area). These values were smaller at the soil of acacia plot $\left(35 \mathrm{~cm}\right.$ and $1763 \mathrm{~cm}^{2}$, respectively) and were the smallest at the soil of pine plot $\left(29 \mathrm{~cm}\right.$ and $\left.616 \mathrm{~cm}^{2}\right)$. All spatial infiltration rates (depth and area) were within the findings of previous studies;

- $\quad$ The initial and stable infiltration rates in acacia plantation have strong positive relationship with the understory vegetation cover. Otherwise, the stable infiltration rate in both plantations has medium positive relationship with porosity and weak negative relationship with soil moisture while the initial infiltration rate has medium negative relationship with the soil moisture and weak positive with porosity.

Research on soil infiltration is very important in the field of environmental protection and water resources management. This topic will contributes significantly in predicting forest floods, limiting surface runoff and preventing soil erosion. It is therefore necessary to determine the infiltration and retention of soil. The further studies should cover more forest conditions and different types of land use. Moreover, the next study should consider to assess the impacts of soil types on infiltration process to clarify issue.

\section{References}

[1] Alaoui, A., Goetz, B. (2008). Dye tracer and infiltration experiments to investigate macrospore flow. Soil Science Section, Geoderma, 144, 279-286.

[2] Chyba, J., Kroulik, M., Lev, J and Kumhala, F. (2013). Influence of soil cultivation and farm machinery passes on water preferential flow using brilliant blue dye tracer. Agronomy Research, 11, 25-30.
[3] David, H.A. (1982). Effects of Nutrient Accumulation by Aspen, Spruce, and Pine on Soil Properties. Soil Science Society of America Journal, 46(4), 853-861.

[4] Dowling, A.J.,Webb, A.A., and Scanlan, J.C. (1986). Surface soil chemical and physical patterns in a brigalow-Dawson gum forest, central Queensland. Australian Journal of Ecology, 11, 45-47.

[5] Dune, T., Zhang, W., Aubry, B.F. (1991). Effects of rainfall, vegetation and microtopographyon infiltration and runoff. Water Resources Research, 27 (9), 2271-2285.

[6] Dung, B.X. (2016). Soil infiltration characteristics of different land use types at Luot Mountain, Xuan Mai, Hanoi. Journal of Forestry Science and Technology, 4, 47-58. (in Vietnamese with abstract in English).

[7] Dung, B.X., Miyata, S., Gomi, T. (2011). Effect of forest thinning on overland flow generation on hillslopes covered by Japanese cypress. Ecohydrology, 4, 367378.

[8] Dung, B.X., Thuy, T.T.D., Son, L.T. (2015). Impact of the material covered on soil surface runoff generation and soil erosion in experimental scale. Journal of Forestry Science and Technology, 3, 29-39 (in Vietnamese with abstract in English).

[9] Dung, B.X., Linh, N.T.M, Thuy, T.T., Linh, P.T., Kha, L.N., Trang, P.T.T. (2017). Infiltration characteristics of soil under Eucalyptus plantation forest in headwater of Viet Nam. Journal of Forestry Science and Technology, 2 63-74. (in Vietnamese with abstract in English).

[10] Gardner, W.R. (1964). Relation of Root Distribution to Water Uptake and Availability. Agronomy Journal, 56, 41-45.

[11] Haws, N.W., Liu, B., Boast, C.W., Rao, P.S.C., Kladivko, E.J., Franzmeier, D.P. (2004). Spatial variability and measurement scale of infiltration rate on an agricultural landscape. Soil Science Society of America Journal, 68, 1818-1826.

[12] Hiraoka, M., Onda, Y., Kato, H., Mizugaki, S., Gomi, T., Nanko, K. (2010). Effects of understory vegetation on infiltration capacity in Japanese cypress plantation. Journal of Japanese Forest Society, 92(3), 145-150. doi: 10.4005/jjfs.92.145. (in Japanese with English summary)

[13] Hoan, L.T. (2014). Forest resources and forestry in Vietnam. Journal of Vietnamese Environment, 6 (2), $171-177$.

[14] Horton, R.E. (1933). The role of infiltration in the hydrological cycle. Transactions, American Geophysical Union, 14, 446-460.

[15] Inagaki, M., Kamo, K., Miyamoto, K. (2011). Nitrogen and phosphorus retranslocation and N:P ratios of litterfal in three tropical plantations: luxurious $\mathrm{N}$ and efficient P use by Acacia mangium. Plant Soil, 341, 295-307. 
[16] Kinnell, P.I.A. (2005). Raindrop-impact-induced erosion processes and prediction: A review. Hydrol. Processes, 19, 2815-2844.

[17] Linh, P.T., Dung, B.X., Bao, T.Q. (2018). Infiltration characteristics of soil under Cinnamon and Acacia plantation forest in headwater of Vietnam. Vietnam Journal of Forest Science, 4, 83-96.

[18] May, B.M., Attiwill, P.M., (2003). Nitrogen-fixation by Acacia dealbata and changes in soil properties 5 years after mechanical disturbance or slash-burning following timber harvest. Forest Ecology and Management, 3, 339-355.

[19] Ministry of Agriculture and Rural Development 2012. Information of forestry situation.

[20] Mugunga, C.P., Mugumo, D.T., (2013). Acacia sieberiana effects on soil properties and plant diversity in Songa Pastures - Rwanda. International Journal of Biodiversity, 2013, 11-24.

[21] Onda, Y., Yukawa, N. (1995). The influence of understories on the infiltration capacities of Chamaecyparis obtusa plantation (I)- Laboratory Experiment. Journal of Japanese Forestry Society, 77, 224-231 (in Japanese with English abstract).
[22] Pagliai, M., Vignozzi, N. (2004). The Soil Pore System as an Indicator of Soil Quality. Soil and Tillage Research, 79, 131-143.

[23] Samingan., Sudirman, L.I. (2009). Fungal Succession and Decomposition of Acacia mangium Leaf Litters in Health and Ganoderma Attacked Standings. HAYATI Journal of Biosciences, 16 (3), 109-114.

[24] Santos, F.M., Fontes, M., Balieiro, F.C., Chaer, G.M. (2017). Understanding the enhanced litter decomposition of mixed-species plantations of Eucalyptus and Acacia mangium. Plant and Soil, https://doi.org/10.1007/s11104-017-3491-7.

[25] Sharma, M.L., Gander, G.A., Hunt, C.G. (1980). Spatial variability of infiltration in a watershed. Journal of Hydrology, 45, 101-122.

[26] Shinohara, Y., Misumi, Y., Kubota, T., Nanko, K. (2019). Characteristics of soil erosion in a moso-bamboo forest of western Japan: Comparison with a broadleaved forest and a coniferous forest. Catena, $172,451-460$.

[27] Weiler, M.H., McGuire, K.J., and McDonnell, J.J. (2002). Infiltration Dye Experiment. Journal of Hydrology, 14, 6-8. 